\title{
Constructivism Approach: Changes in Orientation of Indonesia in the North Natuna Sea to China's Claims
}

\author{
Herry Wahyudi \\ Universitas Abdurrab, Riau, Indonesia \\ Email:Herry.wahyudi@univrab.ac.id \\ Luerdi \\ Universitas Abdurrab, Riau, Indonesia \\ Email:Luerdi@univrab.ac.id
}

\begin{abstract}
This article discusses the constructivism approach in describing Indonesia's changing orientation in the North Natuna Sea towards China's claims. In 2013-2014 Natuna was discussed by the central government in Jakarta in economic, cultural, and tourism aspects. In 2015, Natuna was officially reviewed by the Indonesian government from a security perspective. This security perspective is in the context of sovereignty and national security. This article aims to look at the change in Indonesia's direction in positioning the North Natuna Sea after being claimed by China as part of its territory. This article uses the constructivism theory of Alexander Went. Constructivism is a structural theory of the international system which has basic claims: the state is the most principled unit of analysis in international political theory, the key structure in the state system is inter-subjective from matter, and identities and interests are constructed of social structures, formed naturally by themselves. This article shows that Indonesia as an actor in constructivism is able to change its policy orientation through the perception of the challenges faced in the North Natuna Sea. This article uses a qualitative approach with the method of collecting data from a literature study.
\end{abstract}

Keywords: Indonesia, constructivism, change of orientation, threat, China, North Natuna Sea 


\begin{abstract}
Abstrak
Artikel ini membahas pendekatan konstruktivisme dalam mendeskripsikan perubahan orientasi Indonesia di Laut Natuna Utara terhadap klaim Tiongkok. Tahun 2013-2014 Natuna didiskusikan oleh pemerintah pusat di Jakarta hanya dalam aspek ekonomi, budaya, dan pariwisata. Pada tahun 2015, Natuna resmi dikaji oleh pemerintah Indonesia dalam perspektif keamanan. Perspektif keamanan ini dikaitkan dengan konteks kedaulatan dan keamanan nasional. Artikel ini bertujuan untuk melihat perubahan orientasi Indonesia dalam memposisikan perairan Natuna Utara setelah diklaim oleh Tiongkok sebagai bagian dari kawasannya Orientasi Indonesia dalam melihat perairan Natuna Utara mulai berubah yang sebelumnya lebih pada orientasi pengembangan aktivitas ekonomi beralih ke orientasi pertahanan-keamanan di tengah hubungan ekonomi Indonesia dan Tiongkok. Artikel ini menggunakan teori konstruktivisme dari Alexander Went. Konstruktivisme merupakan teori struktural dari sistem internasional yang memiliki klaim dasar: negara merupakan unit analisis yang paling prinsip dalam teori politik internasional, kunci struktur di dalam sistem negara bersifat inter-subjektif dari pada bersifat material, dan identitas dan kepentingan negara terkonstruksi oleh struktur sosial, ketimbang terbentuk sendiri secara alamiah. Artikel ini menunjukkan bahwa Indonesia sebagai aktor dalam konstruktivisme mampu mengubah orientasi kebijakannya melalui persepsi ancaman yang dihadapi di Laut Natuna Utara. Artikel ini menggunakan pendekatan kualitatif dengan metode pengumpulan data studi kepustakaan.
\end{abstract}

Kata Kunci: Indonesia, konstruktivisme, perubahan orientasi, ancaman, Tiongkok, Laut Natuna Utara

\section{INTRODUCTION}

At present the maritime conditions of a country can reflect its geopolitical thinking policy. The concept of maritime strategy adopted by several countries in the world is certainly based on maritime power. The maritime power itself is understood as not only reflecting the power at sea represented by a country's navy but also in a broad understanding as reflecting the extent to which 
a country is optimally using its maritime (Sakhuja, 2011).

China is a country that has a highly developed geopolitical thinking strategy in Asia. After running the Greater Mekong Subregion (GMS) strategy in 1992, China once again made a grand strategy on maritime affairs in line with its current domestic economic and military development. On October 3, 2013, the Chinese President Xi Jinping officially announced the concept of the 21st Century Maritime Silk Road before the Indonesian parliament. The core of policy was the development of marine infrastructure from the mainland China to the main ports in the South Asia, Southeast Asia, Middle East and Europe by combining land and sea routes referred to the term of OBOR (One Belt One Road) (Suropati, Sulaiman, \& Montratama, 2016). This certainly became a hope and a challenge for Indonesia; a hope to establish better and more sustainable cooperation with China and a challenge of China's economic and military development accompanied by its aggressiveness in the ASEAN region, especially in the South China Sea conflict.

Of the several cases that can be seen related to the North Natuna Sea, Indonesia prefered hedging strategies in dealing with China by maintaining good relations while maintaining sovereignty (Syauqi \& Abrar, 2018). This strategy was chosen to maintain economic relations between the two countries. The construction of China's threat in the North Natuna Sea remained a threat to Indonesia's sovereignty rather than that to economic relations between the two countries. Indonesia also took another strategy to rename of the South China Sea associated with the Indonesian Exclusive Economic Zone (EEZ) into the North Natuna Sea in 2017, but it was not effective in changing the construction of China's threat to Indonesia (Syauqi \& Abrar, 2018).

Hedging according to Evelyn Goh is a series of strategies aimed at avoiding situations or as a backup in situations where a country cannot choose strategies such as balancing, bandwagoning or neutrality. Goh sees that hedging strategies consist of indirect or soft balancing as well as engagement at political, economic and strategic levels and involve major powers in the region to maintain regional stability (Syauqi \& Abrar, 2018). Indonesia would find it difficult to implement a balancing strategy since it still needed the Chinese investment. On the other hand, the bandwagoning 
strategy was very unfavorable as it would cause dependency on other major power countries.

In addition to hedging, Indonesia took advantage of diplomatic efforts to resolve incidents in the Natuna waters with China. UNCLOS could be the success of Indonesia's diplomacy in expanding its territorial waters and making it an archipelagic nation. Indonesia could use its diplomacy again by carrying out the UNCLOS principles. Starting with the Djuanda Declaration on December 13, 1957 and ending at UNCLOS 1982, Indonesia succeeded in expanding its territorial waters 3-6 million $\mathrm{km} 2$ without military expedition activities, as revealed by Arif Havas Oegroseno (2017) (Mcrae, 2019). The problem of using such strategy is that China seems to be inconsistent with UNCLOS. In addition, due to the fact that all ASEAN countries also ratified UNCLOS as well as China which ratified it in 1996, the strategy would become a strategy of mutual claims between China and countries in the ASEAN region. The South China Sea is a "hole in the doughnut" which is ready to be exploited by countries that have succeeded in capturing these waters. The implication is that Indonesia's diplomacy toward China will be "charm-offensive" (Mcrae, 2019).

Indonesia's military infrastructure development efforts also began in 2012. After the Chinese coastguard incident which crashed into an Indonesian fishing patrol boat in October 2013, Indonesia began to pay attention to the military aspect of Natuna waters. October 2016 and May 2017 were the climax, when the Indonesian President Joko Widodo was immediately present to see military training in the Natuna waters by riding KRI Imam Bonjol. President Joko Widodo also brought several related Ministers to the meeting on the warship. Since then, it is believed that the Natuna is a priority of the Indonesian Defense Planning 2024.

The last strategy that could be applied by Indonesia was to use the economy. President Joko Widodo instructed the Ministry of Fisheries to build a fishery center in Natuna waters. In addition, bringing 400 fishing boats (fishermans) from Java to Natuna was also an effort to strengthen Indonesia's presence in Natuna waters (JMOL, 2019).

Theoretical framework and research method

Alexander Wendt's simple opinion about constructivism is that international politics consists 
of intellectual endeavors in building an international system as a "social construction" which contrasts sharply with positivist traditions and materialist conceptions as echoed by the groups of realism and liberalism. The similarity between realism, liberalism and constructivism is that they both raise anarchist traditions (culture of anarchy), but for constructivism the anarchist tradition is constructed by the state itself which is a contestation of ontology and epistemology positivism. The constructivism socially challenges the structure of human life as the main tradition of material phenomena and rationally debates the function of humans not only as regulators of behavior (behavior-regulating) but constructed identity and interests.

Constructivism is a structural theory of the international system that has basic claims: (1) the state is the most principle unit of analysis in international political theory, (2) key structures in the state system are inter-subjective rather than material, (3) and identity and state interests are constructed by social structures, rather than naturally formed themselves (Behravesh, 2011).

"Identity" is a concept that is very calculated in the perspective of constructivism and is a crucial part in the interpersonal and international interactions. Wendt subjectively states that an actor's intentions shape motivation and attitudes that are rooted in selfunderstanding. The identity mentioned by Wendt is not only as a unit but also as an understanding and that understanding is also understood and represented by other parties. So there are internal and external aspects of subjectivity in understanding Wendt's constructivism.

Indonesia as a country in the perspective of constructivism is the most principle unit of analysis in international political theory, the identity and interests of the state are existent thanks to the social construction rather than naturally formed. Indonesia issued a number of regulations in the form of laws such as the Law No. 43 of 2008 concerning State Territories and Law No. 17 of 1985 concerning ratification of UNCLOS 1982. In addition, Indonesia established a national border management body chaired by the Minister of the Interior in accordance with the Presidential Regulation No. 44 of 2017 (Purba. Sampe L, 2020). 


\section{RESULT AND DISCUSSION}

\section{Natuna's position for Indonesia}

In 2013-2014 Natuna was discussed by the central government in Jakarta only in economic, cultural and tourism aspects (Meyer, Nurmandi, \& Agustiyara, 2019). The relations between Indonesia and China were considered to be still warm that year and the two countries agreed that the problem in Natuna waters was only the illegal fishing problem. However, the orientation of Natuna's position for merely economic, cultural and tourism aspects changed after China redefined the nine dash line in March 2014.

In 2015, Natuna was officially reviewed by the Indonesian government in a security perspective. The security perspective was related to the context of Indonesia's sovereignty and security. President Joko Widodo in 2015 instructed the Head of the National Planning Agency (BAPENAS), Andrinof Chaniago to study the Natuna to be a stronghold of the Indonesian military fortress or in other words make the Natuna the Pearl Harbor of Indonesia (Meyer et al., 2019).

In 2016, the Natuna was fully reviewed by the Indonesian government as a security issue, this can be seen from several indications such as budget allocation for military installations in the region, efforts to increase 5,000-12,000 personnel to serve in the region and protest notes delivered to China. Furthermore, prioritizing incidents in the Natuna waters became a matter of national security (Meyer et al., 2019).

China first released the nine dash line claim in 1993 and since then the escalation of the territorial boundary violation was in the ambivalence curve situation, including with Indonesia. China has always been playing a double standard towards Indonesia in the case of the Natuna waters incident since 2016. China seemed to be careful in responding to Indonesia regarding the incidents. China's perception towards Indonesia is divided into two. First, it still considers that the incidents in the Natuna waters still exist. Secondly, the strategic relations between the two countries continue to run well. The Chinese perspective can be analyzed through the theory of images from Hermann and Fischerkeller (1995) which states that the structure of relations between countries is influenced by the image of each built between the two countries (Kartikasari, 2019). There are 5 types of images built by one country against another: 
first, enemy image considering another country as a threat. Second, degenerate image considering the possibility of a country can be exploited. Third, the colony image considering another country weak and inferior and incomparable to it. Fourth, ally image considering another country balanced and equal so that it can be made an ally. Fifth, imprealist image considering itself stronger and could threaten other countries.

China placed Indonesia in the category of an ally image regarding the Natuna waters incidents. This was because Indonesia was able to cooperate with the ongoing economic ties and Indonesia was considered to have the same capabilities and culture as China (Kartikasari, 2019).

\section{Troops and Equipment Develop- ment}

In securing the North Natuna Sea, the TNI deployed 600 personnel by involving 5 warships (KRI) and a Boeing aircraft. According to the Commander of the Joint Regional Defense Command I (Pangkogabwilhan I) Vice Admiral (Laksdya) TNI Yudo Morgono the entire personnel and the Armed Forces would be prepared for 18 combat alert operations. Initially only 5 warships were prepared by the Navy, seeing the increasing intensity of the activities of Chinese fishing vessels and Coastguards in the region, the TNI again increased its security as a result of the construction of threats seen by the TNI. There were 2 warships with Frigate types and 2 tanker types which were also alerted by the Navy to respond to the threat (Kompas, 2020).

In addition to preparing combat standby operations, the government through the Coordinating Ministry of Political, Legal and Security Affairs and the Ministry of Fisheries and Maritime Affairs in coordination with BAKAMLA (Indonesia's Maritime Security Agency) also took a role in securing the North Natuna Sea. According to the Head of BAKAMLA Vice Admiral Achmad Taufiqoerrachman, the additional strength of BAKAMLA was natural in nature if there was a threat to maintain sovereignty in accordance with ongoing conditions, namely using the white "hull strategy" rather than "the gray hull strategy"(CNNIndonesia, 2020).

The term "Hull" in the shipping world means the body of boat. "White hull" means the hull of a ship with white color which is identical 
to "coast guard" or territorial guard who does not have military power to fight, is the same as sea police, while "Gray Hull" means a ship with hull or gray body of the ship the ashes identified with a naval military ship of a country that has the power of war for large scale. All of these terms are in accordance with Harold Kearsley's theory in his book "Maritime Power and the 20th Century” (Haje, 2020).

From the BAKAMLA slap, it could be concluded that the construction of threats perceived by the TNI was different from BAKAMLA. BAKAMLA was more about negotiation and diplomacy in the process of maintaining sovereignty in the North Natuna Sea, while the TNI was more on the use of hard power, thus BAKAMLA remained in the established line in handling cases in the North Natuna Sea. This was in line with foreign policy outcomes in the North Natuna Sea and efforts to deal with Chinese ambitions in these waters using the concept of humble-hard power. This concept is introduced by Adam Nieves-Johnson in his book entitled "A Bilateral Analysis of the South China Sean Dispute: China, the Philippines, and the Scarborough Shoal" meaning that humble-hard power is a new form of hard power without military intimidation (Robertua \& Sinaga, 2018).

Indonesia would not show a military threat but peaceful diplomatic activities while still using power without showing indications of great contradiction in the international world. Such form of response means that bilateral relations between the two countries that are currently implementing several mega projects are not disturbed, one of which is the rapid train project in several cities in Indonesia. With a focus on investment in the form of mega projects carried out by China in Indonesia, the two countries do not appear to involve problems in the North Natuna Sea because of the economic interests. However, with the presence of the humble-hard power concept Indonesia can still maintain its sovereignty without disrupting Chinese investment in Indonesia.

\section{Building Defense Infrastructure}

In term of defense infrastructure, Indonesia is experiencing the increased defense infrastructure construction. Indonesia used to have a defense infrastructure orientation towards the land (continental oriented) and then it has been paying more attention 
to the maritime-oriented defense infrastructure. This is in line with Joko Widodo's foreign policy which is to make Indonesia a World Maritime Fulcrum as a national goal and be defined in accordance with Indonesia's maritime policy to become a maritime country which is sovereign, advanced, independent, strong and able to contribute positively to world security and peace. The World Maritime Fulcrum is aimed at not only making Indonesia an archipelagic state (being a maritime) but also making Indonesia a country that has maritime power (Seapower) (Suropati, Montratama, \& Sulaiman, 2018). So that in the Indonesian conflict with China in the North
Natuna Sea, Indonesia built a medium-term strategic plan on the Natuna Island called an Integrated TNI Unit on Natuna Island (Eksa, 2018). The unit will involve intergenerational TNI officers from TNI Headquarters and Force Headquarters, whose main purpose is to provide deterrence effects on issues in the North Natuna Sea. And Hadi Tjajanto also said that the project will continue on other strategic islands in Indonesia, in accordance with the stages of the development of the next strategic plan (Eksa, 2018).

The integrated TNI Unit consists of all Army, Navy, Air Force TNI Units as shown in the following table.1;

Table. 1 The Integrated TNI

Unit on the Natuna Island

\begin{tabular}{|c|l|l|l|l|}
\hline No & \multicolumn{1}{|c|}{ Army } & \multicolumn{1}{|c|}{ Navy } & \multicolumn{1}{|c|}{ Air Force } & $\begin{array}{l}\text { Supporting } \\
\text { Facilities }\end{array}$ \\
\hline 1 & $\begin{array}{l}\text { Composite } \\
\text { Battalion (Kompi } \\
\text { Zeni Tempur) }\end{array}$ & $\begin{array}{l}\text { Marine } \\
\text { Composite } \\
\text { Company }\end{array}$ & $\begin{array}{l}\text { Integrative } \\
\text { Hangar }\end{array}$ & $\begin{array}{l}\text { TNI Health } \\
\text { Hospital }\end{array}$ \\
\hline 2 & $\begin{array}{l}\text { Air Defense } \\
\text { Artillery Unit }\end{array}$ & Navy Port & $\begin{array}{l}\text { Hangar unmanned } \\
\text { aerial vehicle (UAV) } \\
\text { squadron }\end{array}$ & \\
\hline 3 & $\begin{array}{l}\text { Baterai Field } \\
\text { artillery }\end{array}$ & & & \\
\hline
\end{tabular}

Source: Processed by researchers from various sources 
The TNI Commander also added that the Natuna Integrated TNI Unit would continue to develop, the plan would be refined with an operational control system based on network centric warfare capabilities (Eksa, 2018). The initial process of this unit was the formation of units, personnel, and unit materials that would be carried out by each TNI unit's chief of staff. The TNI Integrated Unit will later become a permanent and integrated organization in one command, so that at any time it is ready to be deployed to carry out military operations.

\section{Boarding Patrols}

Efforts to secure the North Natuna Sea are not only at the level of the Indonesian coastguard (Bakamla) or the TNI. The agreements among 13 Indonesian ministries or institutions, including fishing groups and Pertamina organizations also contribute to such effort. This was puposively made as the foundation of institutional work related to the synergy and optimization, supervision, security and utilization of fish resources in the region. The construction of threats from China has become a threat whose scale is not only to the level of the state but also to that of community as the smallest part of the state element. Bakamla in this matter will be tasked with escorting Indonesian fishing vessels that conduct fishing activities in the region (Okezone, 2020). The presence of Indonesian fishermen in the region will strengthen the principle that region is "dejure" and "traditionally" owned by Indonesia, even though China uses the traditional propositions and the traditional journey of their fishermen in conducting fishhandling activities in the region.

Indonesia through BAKAMLA also conducted an analysis of the strategy to be applied in the northernmost western waters. Seeing from the development of the security situation, BAKAMLA applies the concept of the Indonesian Maritime Strategy which rests on 3 main pillars namely (Yoga, 2020):

\section{Sustainable Presence at Sea}

2. Sustainable Exploration of the Sea

3. Sustainable Trust Build by Sea

The strategy presented indicates that Indonesia continues to prioritize a soft approach in dealing with the threat of China in the North Natuna Sea. Indonesia does not want a titfor-tat with China. The construction of threats in the North Natuna Sea is fabricated directly by Indonesia as a sovereignty issue that is faced 
by a country in general without disrupting other strategic relations with China.

This strategy was conveyed by the Head of BAKAMLA Laksdya TNI Aan Kurnia in a coordination meeting with 13 ministries or institutions led by Minister of Political Law and Security Affairs Mahfud MD (Ridwan, 2020).

"So far we have not been there, so we have increased the volume of attendance in Indonesian waters, both in territorial waters and in sovereign rights waters, EEZ to the high seas. That we guard with patrol activities and economic activities in the future. Because after "later there will be more normal fishing activities carried out there," (Ridwan, 2020).

On the other hand, in the case of border patrols in the North Natuna Sea, Indonesia once received an offer from the United States to establish cooperation in sea patrols in the North Natuna Sea. This offer came from United States Secretary of Defense James Mattis in 2018 during a visit to Jakarta. The patrol in the North Natuna Sea is one of the points discussed in the framework of cooperation between the two countries. Mattis himself dubbed the situation of the South China Sea and Chinese activities in the region as "mad dogs" because of disputes that involved too many actors (Asmardika, 2018). Mattis also appreciated that Indonesia renamed the part of the South China Sea covering the territory of the Republic of Indonesia to the North Natuna Sea.

\section{Conclusion}

The identity as an archipelagic country is both an advantage and a disadvantage for Indonesia in several aspects. In the economic aspect, it will certainly result in the achievement and fulfillment of very high national interests, but in term of security it is also the riskiest aspect of threats from other parties, espeacilly from state actors either collectively or individually.

The North Natuna Sea is one of the waters that Indonesia is currently giving special attention. This is due to the impact of the threat posed by China's aggressiveness in these waters. The construction of the threat posed by China has made Indonesia change the orientation of the management of these waters from the previously economic-oriented aspec to the security-orientated one. Several security border policies have been imposed in these waters such as developing troops and defense equipment, building military infrastructure and strengthening security patrol collaboration. 


\section{BIBLIOGRAPHY}

Asmardika, R. (2018). AS Tawarkan Bantu Awasi Natuna Utara, Ini Kata Pengamat. Retrieved May 8, 2020, from https://news.okezone.com/ $\mathrm{read} / 2018 / 01 / 26 / 18 / 1850512 /$ as-tawarkan-bantu-awasi-natuna-utara-ini-kata-pengamat

Behravesh, M. (2011). The Thrust of Wendtian Constructivism. In https://www.e-ir.info/ (pp. 1-12). https://www.e-ir.info/. Retrieved from https://www.eir.info/2011/03/09/the-thrustof-wendtian-constructivism/

CNNIndonesia. (2020). Dibantu TNI BAKAMLA Tambah Kekuatan Hadapi China di Natuna. Retrieved March 9, 2020, from https:// www.cnnindonesia.com/nasional/20200103175336-20-462241/ dibantu-tni-bakamla-tambahkekuatan-hadapi-china-di-natuna

Eksa, G. (2018). Panglima TNI Resmikan Satuan Terintegrasi Natuna. Retrieved March 3, 2020, from https://mediaindonesia. $\mathrm{com} / \mathrm{read} / \mathrm{detail} / 205057$ panglima-tni-resmikan-satuanterintegrasi-natuna

Haje, D. (2020). Apa Arti dari Istilah White Hull dan Grey Hull di Perkapalan. Retrieved March 9, 2020, from https://id.quora.
com/Apa-arti-dari-istilahwhite-hull-dan-grey-hull-diperkapalan

JMOL. (2019). Armada Kapal Patroli Laut "Sea and Coast Guard" Indonesia December 12, 2019. Retrieved May 20, 2020, from https://jurnalmaritim. com/armada-sea-and-coastguard-indonesia/

Kartikasari, A. (2019). Indonesia's Image From China's Perspective on South China Sea Dispute (A Preliminary Study on China's Perception on Indonesia). Global: Jurnal Politik Internasional, 21(2), 176-197. https://doi.org/10.7454/global. v21i2.404

Kompas. (2020). Amankan Laut Natuna, TNI Siapkan 18 Operasi Siaga Tempur. Retrieved March 9, 2020, from https://regional.kompas.com/ $\mathrm{read} / 2020 / 01 / 05 / 14070091 /$ amankan-laut-natuna-tnisiapkan-18-operasi-siagatempur-?page $=$ all.

Mcrae, D. (2019). Indonesia's South China Sea Diplomacy: A Foreign Policy Illiberal Turn? Journal of Contemporary Asia, 49(05), 759-779. https://doi.org/10.1080 /00472336.2019.1601240

Meyer, P. K., Nurmandi, A., \& Agustiyara, A. (2019). Indo- 
nesia's Swift Securitization of the Natuna Islands How Jakarta Countered China s Claims in the South China Sea. Asian Journal of Political Science, 27(1), 70-87. https://doi.org/1 $0.1080 / 02185377.2019 .1590724$

Okezone. (2020). Kapal Bakamla Gelar Patroli dan Kawal Nelayan di Laut Natuna Utara. Retrieved March 9, 2020, from https://nasional.okezone.com/ $\mathrm{read} / 2020 / 03 / 09 / 337 / 2180256 /$ kapal-bakamla-gelar-patrolidan-kawal-nelayan-di-lautnatuna-utara

Purba. Sampe L. (2020). Aspek Geografis Kemaritiman Kawasan Perbatasan di Natuna - Arafuru. Retrieved March 9, 2020, from https://katadata. co.id/opini/2020/02/08/aspekgeostrategis-kemaritimankaw as an-perbatas an-dinatuna-arafuru

Ridwan, A. (2020). 13 institusi kerja sama amankan Laut Natuna Utara. Retrieved May 20, 2020, from https://www.alinea.id/ nasional/13-institusi-kerjasama-amankan-laut-natunautara-b1ZIk9rIO

Robertua, V., \& Sinaga, O. (2018). Indonesia in the South China Sea Dispute: Humble-Hard Power. Jurnal Global \& Strategis, 11(2),
73. https://doi.org/10.20473/ jgs.11.2.2017.73-83

Sakhuja, V. (2011). Asian Maritime Power in the 21st Century: Strategic Transaction China, India and Southeast Asia. India: Pentagon Press.

Suropati, U., Montratama, I., \& Sulaiman, Y. (2018). Indonesia INC. Peta Jalan Menuju Poros Maritim Dunia. Jakarta: Elex Media Komputindo.

Suropati, U., Sulaiman, Y., \& Montratama, I. (2016). Arungi Samudra Bersama Sang Naga: Sinergi Poros Maritim Dunia Abad ke-21. Jakarta: Elex Media Komputindo.

Syauqi, D., \& Abrar, M. I. (2018). Hedging Sebagai Strategi Indonesia untuk Menghadapi Klaim Cina di Laut Cina Selatan. Indonesia Foreign Policy Review, 4(November), 1-14. Retrieved from https:// www.researchgate.netpublicati on/328686834\%0AHedging

Yoga, G. (2020). Kepala Bakamla RI Hadiri Rapat Pembahasan Perkembangan Situasi Keamanan Laut Natura Utara. Retrieved May 8, 2020, from https:// bakamla.go.id/home/artikel_le ngkap/4535/2edf9423e5c301a2 2744 cce $46 \mathrm{c} 1 \mathrm{~d} 4 \mathrm{fcf}$ 